Western North American Naturalist 69(3), ( 2009, pp. 329-334

\title{
DISTRIBUTION RECORDS AND COMMENTS ON MAMMALS IN WESTERN SOUTH DAKOTA
}

\author{
Steven G. Platt ${ }^{1,4}$, Zannita Fast Horse ${ }^{1}$, Thomas R. Rainwater ${ }^{2}$, and Stanlee M. Miller ${ }^{3}$
}

\begin{abstract}
The mammal fauna of western South Dakota is imperfectly known; in particular there is a notable paucity of data from Indian reservations in the region. We collected mammals from January 2003 through May 2006 using a variety of standard methodologies, including trapping with snap-traps and Macabee traps, shooting, and salvaging road- and hunter-killed animals. Herein we provide 23 specimen-based county records representing 17 species of mammals. In addition, a photo record constitutes the first report of Dasypus novemcinctus from South Dakota and the northernmost record in the United States. The possible local extirpation of Marmota flaviventris in the southern Black Hills is discussed.
\end{abstract}

Key words: Black Hills, Dasypus novemcinctus, mammals, Marmota flaviventris, Pine Ridge Indian Reservation, South Dakota.

Knowledge of species distributions is fundamental to understanding community and ecosystem dynamics (Andrewartha and Birch 1954), and acquiring baseline data on distributions of even common species is important (Dodd and Franz 1993, Platt et al. 1999). However, accurate determination of the distributions of most species in the United States has yet to be achieved (Gibbons et al. 1997). In particular, the mammal fauna of western South Dakota is imperfectly known (Barnes and Linder 1982, Higgins et al. 2002). While previous faunal inventories in western South Dakota have focused on Harding County (Anderson and Jones 1971), Bennett County (Jones et al. 1978), Lacreek National Wildlife Refuge (Wilhelm et al. 1981), Wind Cave National Park (Duckwitz 2001), and the Black Hills (Stebler 1939, Turner 1974), only cursory surveys and opportunistic collecting have been conducted throughout much of the region. Moreover, there is a notable paucity of data on the biota of many Indian reservations, in part due to the difficulty of obtaining access to tribal lands (Chiszar et al. 1994). Recently, Higgins et al. (2002) summarized mammal distribution records for each county in South Dakota and categorized these as based on museum specimens, literature references, literature references supported by museum specimens, or field verifications by credible professionals. Herein we report additional mammal distribution records based on museum specimens (or in one case a published photograph) collected in southwestern South Dakota and provide comments on these and other species of interest. It is important to note that museum specimens with accompanying collection data not only provide an unequivocal record of species occurrence at a particular time and location (Hall 1962) but also constitute essential data sets in studies of biogeography, ecology, taxonomy, and evolution, which are useful for establishing regional conservation priorities (Remsen 1995, Winker 1996, McCarthy 1998, Shaffer et al. 1998, Pergams and Nyberg 2001).

\section{Methods}

We collected mammals in Bennett, Custer, Fall River, Jackson, Jones, Shannon, and Pennington counties of southwestern South Dakota from January 2003 through May 2006. This region falls within the unglaciated Missouri Plateau Physiographic Province, and experiences a semiarid continental climate with hot, dry summers and cold winters (Hudson 2002). The Black Hills are an isolated mountainous formation (maximum elevation $2207 \mathrm{~m}$ ) comprising approximately $10,000 \mathrm{~km}^{2}$ in southwestern South Dakota and adjacent counties

${ }^{1}$ Department of Math and Science, Oglala Lakota College, Box 490, Kyle, SD 57752-0490.

${ }^{2}$ Corresponding author. The Institute of Environmental and Human Health, Department of Environmental Toxicology, Texas Tech University, Box 764, Jefferson, TX 75657. E-mail: trrainwater@gmail.com

${ }^{3}$ Campbell Museum, Department of Biological Sciences, 132 Long Hall, Clemson University, Clemson, SC 29634-0314.

${ }^{4}$ Present address: Department of Biology, Box C-64, Sul Ross State University, Alpine, TX 79832. 
of Wyoming (Turner 1974). The Hogback, a sandstone ridge rising to $1300 \mathrm{~m}$ forms the outer rim of the Black Hills and encloses the Red Valley in Fall River and Custer counties. The Black Hills are surrounded by rolling grassland drained by the Belle Fourche, Cheyenne, and White rivers. Extensions of the sandhill ecoregion that characterizes much of western Nebraska (Hudson 2002) occur in southern Shannon and Bennett counties (Platt et al. 2006). Shannon, Jackson, and parts of Bennett counties are included in the 670,000-ha Pine Ridge Indian Reservation. Detailed descriptions of the vegetation, soils, topography, and climate of southwestern South Dakota are provided elsewhere (Turner 1974, Platt et al. 2006).

We employed a variety of standard methodologies to collect mammals (Jones et al. 1996). Small rodents (mice, voles, and ground squirrels) were collected with snap traps (Museum Special and Victor rat traps), pocket gophers were captured in Macabee traps set in subterranean tunnels, and larger mammals were taken with a 20-gauge shotgun or a .22-caliber rifle. Additionally, we salvaged a number of roadkilled specimens and obtained some large mammals from hunters. Mammal specimens with accompanying field notes were deposited in the Campbell Museum (CUSC), Clemson University, Clemson, South Carolina. We determined distribution records based on comparison with the range maps of Higgins et al. (2002). Taxonomy follows Higgins et al. (2002). Place names are in accordance with U.S. Geological Survey topographical maps.

\section{Species Accounts}

\section{Xenarthra}

Dasypodidae

DASYPUS NOVEMCINCTUS. - A nine-banded armadillo found dead at Sharps Corner (Shannon County) was pictured in the 28 January 2003 issue of the Bennett County Booster (newspaper, copy archived CUSC). Although extralimital records are available from as far north as Illinois, Colorado, Nebraska, and Kansas (Taulman and Robbins 1996, Freeman and Genoways 1998, Merriam 2002, Van Deelen et al. 2002), this newspaper report constitutes the first record of $D$. novemcinctus in South Dakota and the northern-most record in the United States. Local residents speculate that the armadillo was inadvertently transported to South Dakota in large hay bales used as winter feed by area cattle ranchers. Similarly, Taulman and Robbins (1996) attributed records of D. novemcinctus from northern Kansas and southern Nebraska to individuals transported northwards on seasonal agricultural vehicles or released by people returning from southern states. Freeman and Genoways (1998) suggested that increasingly mild winters resulting from global climate change are facilitating the northward expansion of $D$. novemcinctus in the Great Plains. However, barring dramatic warming, we consider it unlikely that populations of $D$. novemcinctus will ever become successfully established in South Dakota because of the extremely low winter temperatures that continue to be typical of the region. Dasypus novemcinctus has little cold tolerance (McNab 1980), and prolonged periods of subfreezing temperatures, even in the southern United States, often result in widespread population die-offs due to hypothermia and starvation (Bond et al. 2002). Taulman and Robbins (1996) concluded that unless climatic change results in considerably warmer minimum winter temperatures in Kansas, D. novemcinctus in the Great Plains is unlikely to expand much beyond its present distribution.

\section{Lagomorpha \\ Leporidae}

LEPUS TOWNSENDII.-White-tailed jackrabbits occur statewide in South Dakota, and specimens are available for most counties. A specimen (3632: BIA Hwy. 2, 30.4 km E Buffalo Gap) collected in Shannon County is a record. We collected 5 additional specimens (3631: Hwy. 18, 3.2 km E state line; 3728: Co. Rd. 5, ca. 4.8 km W Ardmore; 3758: Co. Rd. 5, ca. $1.6 \mathrm{~km} \mathrm{~W}$ Ardmore; 3767: Co. Rd. 5, 24 km W Ardmore; 3803: Co. Rd. 5, 4 km W Ardmore) near Ardmore and Edgemont in Fall River County, where white-tailed jackrabbits were particularly abundant.

\section{Rodentia \\ Sciuridae}

MARMOTA FLAVIVENTRIS. - An isolated population of yellow-bellied marmots occurs in the Black Hills, ranging from the boreal cap down to $1220 \mathrm{~m}$ (Turner 1974). Turner (1974) collected 
a single specimen from the Hogback in western Fall River County. Despite intensive searching throughout this area from 2003 to 2005 , we found no evidence for the continued occurrence of M. flaviventris in Fall River County. An old mandible (4053) we collected from a rock outcropping near the summit of Battle Mountain $(1280 \mathrm{~m})$ constitutes the second record of $M$. flaviventris from Fall River County. Yellow-bellied marmots remain common at higher elevations in the Black Hills.

SCIURUS NIGER. - The eastern fox squirrel occurs throughout most of the state, but specimen-based records from southwestern South Dakota are available only for Jackson and Pennington counties. Based on reports from fur trappers, Wilhelm et al. (1981) listed fox squirrels as "unverified" but likely present in Bennett County. Specimens collected in Custer (3648: Buffalo Gap), Fall River (3616: Hot Springs; 3748: $6.4 \mathrm{~km} \mathrm{~W} \mathrm{Hot} \mathrm{Springs;} \mathrm{3811:}$ Hot Springs), and Shannon (3615: White Clay Creek, Pine Ridge Municipal Park) counties constitute distribution records. Fox squirrels are common in urban habitats of Fall River (Hot Springs, Edgemont) and Shannon (Pine Ridge) counties. We made additional sight records elsewhere in Fall River (Cheyenne River, Battle Mountain) and Shannon (Wounded Knee Creek at Manderson) counties, and a badly damaged roadkill was found in Bennett County (Yellow Bear Canyon). Fox squirrels appear largely restricted to riparian forests and urban habitats in southwestern South Dakota, although we made occasional sightings in Ponderosa pine forest surrounding Hot Springs. Jones (1964) suggested that riparian forest corridors facilitated the westward expansion of fox squirrels onto the Great Plains.

\section{Geomyidae}

GEOMYS BURSARIUS. - The plains pocket gopher occurs throughout eastern and southwestern South Dakota, although specimenbased records are lacking for many counties. Specimens trapped in Fall River County (3684-3685: Horsehead Creek Game Production Area, $14.5 \mathrm{~km} \mathrm{~S}$ Maverick Junction; 4054: Hwy. 18 Bridge at Cheyenne River) are records.

\section{Heteromyidae}

ChaETOdipus hispidus. - Although found throughout western South Dakota, the hispid pocket mouse is not common anywhere (Anderson and Jones 1971, Wilhelm et al. 1981). Only 4 specimens were taken during this study: 3 in Fall River County (3651-3652: Hwy. 18, ca. 16 km S Maverick Junction; 3809: Mickelson Bicycle Trail, $0.25 \mathrm{~km} \mathrm{~S}$ Hwy. 18) and 1 in Shannon County (3702: $1.0 \mathrm{~km}$ E Denby). The latter constitutes a county record. Two specimens from Fall River County were trapped in sandhill habitat and a third was taken from the grass margin of an extensive wheat field. The single specimen from Shannon County was captured by a dog among the stubble of a fallow wheat field.

DIPODOMYS ORDII.—Ord's kangaroo rat occurs throughout most of South Dakota west of the Missouri River. Specimens collected in Shannon County (3700-3701: 3 km W Wakpamani) are distribution records. Those collected in Fall River County (3650 and 3690-3692: Horsehead Creek Game Production Area, 14.5 $\mathrm{km}$ S Maverick Junction) complement an earlier record based on skulls recovered from Barn Owl (Tyto alba) pellets (Martin 1971). Similar to previous reports from South Dakota (Anderson and Jones 1971, Turner 1974, Wilhelm et al. 1981), D. ordii from Shannon and Fall River counties were trapped in areas of sparsely vegetated sandy soil, often in association with big sagebrush (Artemisia tridentata).

\section{Castoridae}

CASTOR CANADENSIS. - Beaver occur throughout South Dakota, but specimen-based records are lacking for most counties west of the Missouri River. A specimen from Shannon County (3641: BIA Hwy. 2, $64.0 \mathrm{~km} \mathrm{E}$ Buffalo Gap) is a record. We found beavers inhabiting springfed wetlands in deep ravines on the southern edge of the White River Badlands. With the exception of willow (Salix spp.) scrub, woody vegetation was absent from this site and beavers constructed an extensive network of dams (one measuring $2.0 \mathrm{~m}$ high) using cattails (Typha sp.) and mud. Lodges were constructed of willow twigs, grass, and mud. Similar to our observations, Anderson and Jones (1971) noted that beavers in northwestern South Dakota were not restricted to wooded habitats and that they constructed impoundments in grasslands. However, in northwestern South Dakota beavers constructed bank dens rather than lodges, presumably due to the paucity of suitable woody material. 
Cricetidae

REITHRODONTOMYS MEGALOTIS. - The western harvest mouse is distributed statewide in South Dakota, but specimens are unavailable for many counties. Specimens trapped in Jones (3707-3708, 3720-3721: $0.4 \mathrm{~km} \mathrm{E} \mathrm{jct.} \mathrm{of}$ Interstate 90 and Hwy. 83) and Shannon (4062: BIA Hwy. 2, 30.5 km E Buffalo Gap) counties constitute records. These specimens were trapped in mesic grassland and sandhill habitat in Jones and Shannon counties, respectively.

PEROMYSCUS LEUCOPUS. - The white-footed mouse occurs throughout western South Dakota, and specimens are available from most counties. Specimens trapped in Shannon (3825, 3830-3834: White Clay Creek at BIA Hwy. 41, 0.2 km NE Oglala Lakota College Center) and Jones (3703-3704: $0.4 \mathrm{~km} \mathrm{E} \mathrm{jct.} \mathrm{of} \mathrm{Inter-}$ state 90 and Hwy. 83) counties are records. Specimens from Shannon County were collected in riparian thickets, while those from Jones County were taken in a wooded shelterbelt bordering a small wetland.

MiCROTUS OCHROGASTER.-Prairie voles are abundant in xeric grasslands of southwestern South Dakota, and museum specimens are available from most counties west of the Missouri River. Specimens trapped in Shannon County (3664 and 3724: BIA Hwy. 2, $30.5 \mathrm{~km}$ E Buffalo Gap) are distribution records.

MicRotus PENNSYLVANiCUS._-Meadow voles probably occur statewide in South Dakota, but specimens are lacking for most counties west of the Missouri River. Specimens trapped in Fall River (3661, 3823: Cascade Creek, 16 km S Hot Springs) and Shannon (3759-3762: White Clay Creek at BIA Hwy. 41, 0.2 km NE Oglala Lakota College Center) counties represent county records. In both counties, we trapped meadow voles among grasses, sedges, and cattails growing in the wet margins of streams and beaver impoundments.

\section{Muridae}

Mus MUSCULUS. - House mice occur throughout South Dakota, generally in association with human habitation, but surprisingly specimens are lacking for many counties. Two specimens (3707-3708: $0.4 \mathrm{~km}$ E jct. Interstate 90 and Hwy. 83) trapped at a small wetland on the outskirts of Murdo constitute records for Jones County.
Erethizontidae

ERETHIZON DORSATUM.-Porcupines are found throughout western South Dakota, and museum specimens are available for most counties west of the Missouri River. A specimen from Shannon County (3635: BIA Hwy. 2, $30 \mathrm{~km}$ E Buffalo Gap) constitutes a record. Although Wilhelm et al. (1981) did not collect E. dorsatum from Lacreek National Wildlife Refuge in Bennett County, our observation of a badly damaged road-killed specimen and abundant signs of feeding in Yellow Bear Canyon indicate that porcupines occur in this county.

\section{Carnivora}

Procyonidae

PROCYON LOTOR. - Raccoons occur statewide in South Dakota, and specimens are available from most counties west of the Missouri River. A specimen collected in Shannon County (3649: Hwy. 18, $17.6 \mathrm{~km} \mathrm{~W}$ Batesland) is a record. Observations of tracks, sign, and living animals suggest that raccoons are most common in wetland and riparian habitats and are rarely found elsewhere in southwestern South Dakota.

\section{Mustelidae}

TAXIDEA TAXUS.-Although occurring statewide, badgers appear to be uncommon in southwestern South Dakota. Specimens collected in Shannon County (3695: BIA Hwy. 41 at White River Bridge; 3732: BIA Hwy. 2, 42 $\mathrm{km}$ E Buffalo Gap) are records. We observed an adult badger excavating a painted turtle (Chrysemys picta) nest in sandhills of southern Bennett County on 29 June 2004. Wilhelm et al. (1981) also reported sightings of badgers in this area.

\section{Artiodactyla \\ Cervidae}

CERVUS ELAPHUS. - In South Dakota, elk are restricted to the westernmost counties, with the greatest numbers occurring in the upper elevations of the Black Hills (Raventon 1994). Despite being an important game animal in the Black Hills (Millspaugh et al. 2000), specimen-based records are lacking for most counties. Skulls from Fall River (3737: Hwy. 18, 5.0 km W Hot Springs; 3798: ca. 3.0 km N Round Top Hill; 3813: Cold Brook Canyon, ca. 5 km 
NW Hot Springs) and Custer (4128: Hell Canyon, ca. $18 \mathrm{~km} \mathrm{~W}$ Custer) counties are records.

\section{Antilocapridae}

ANTILOCAPRA AMERICANA.-Pronghorn range throughout western and central South Dakota, and specimen-based records are available for most counties except Shannon and Jones counties. Two skulls salvaged in Shannon County (3619: BIA Hwy. 2, 29 km E Buffalo Gap; 3633: Hwy. 18, 40 km W Pine Ridge) are records. Our numerous observations suggest that pronghorn are particularly abundant near Oglala and Cuny Table and the adjacent Buffalo Gap National Grasslands west of the reservation.

\section{Bovidae}

OrEAMNOS AMERICANUS.-Mountain goats became established in the Black Hills after escaping from an enclosure in Custer State Park in 1929 (Turner 1974). By the late 1940s the herd had increased to about 300 and has since remained stable (Higgins et al. 2002). Museum specimens are available only for Pennington County. A skull collected from Custer County (3766: $1.2 \mathrm{~km}$ S Sylvan Lake entrance to Custer State Park) is a record.

\section{ACKNOWLEDGMENTS}

Funding for this project was provided by National Science Foundation grants HRD0349451 and HRD-0123149 to the Department of Math and Science, Oglala Lakota College. Scientific collecting permits were issued by Doug Backlund of the South Dakota Department of Game, Fish, and Parks. We thank Kent Jensen, Jim Taulman, Charles Comes Killing, and Sylvio Mannel for suggesting promising collecting locales. Field assistance was provided by Kalyar Platt, Travis Crabtree, John Beck, J. Otis "Bear" Curlene, and Lewis Medlock. Gratitude is due to Mike Fredenberg and the Department of Math and Science at Oglala Lakota College for supporting this project. An initial draft of this manuscript benefited from the comments of Lewis Medlock and 2 anonymous reviewers. Finally, special thanks are owed to the many residents of Pine Ridge Indian Reservation who kindly granted access to their lands.

\section{Literature Cited}

Anderson, K.W., AND J.K. Jones, JR. 1971. Mammals of northwestern South Dakota. University of Kansas Publications, Museum of Natural History 19:361-393.

Andrewartha, H.G., AND L.C. Birch. 1954. The distribution and abundance of animals. University of Chicago Press, Chicago, IL.

Barnes, T.G., and R.L. Linder. 1982. Small mammal occurrence in South Dakota shelterbelts and movements of Peromyscus maniculatus. Proceedings of the South Dakota Academy Sciences 61:56-63.

Bond, B.T., R.J. WarRen, AND M.I. NELSON. 2002. Winter mortality of adult nine-banded armadillos (Dasypus novemcinctus) on Cumberland Island, Georgia. Georgia Journal of Science 60:209-215.

Chiszar, D., D. Featherman, R. Fuerst, and H.M. Smith. 1994. Observations on the herpetofauna of the Indian reservations of southwestern South Dakota. Bulletin of the Chicago Herpetological Society 29:269-270.

DodD, C.K., JR., AND R. Franz. 1993. The need for status information on common herpetofaunal species. Herpetological Review 24:47-50.

DuckwiTZ, J.J. 2001. Small mammal survey of Wind Cave National Park. Master's thesis, South Dakota State University, Brookings. 95 pp.

Freeman, P.W., AND H.H. GeNOWAYS. 1998. Recent records of the nine-banded armadillo (Dasypodidae) in Nebraska. Southwestern Naturalist 43:491-495.

Gibbons, J.W., V.J. Burke, J.E. Lovich, R.D. Semlitsch, T.D. Tuberville, J.R. Bodie, J.L. Greene, P.H. Niewiarowski, H.H. Whiteman, D.E. ScotT, et AL. 1997. Perceptions of species abundance, distribution, and diversity: lessons from four decades of sampling on a government-managed reserve. Environmental Management 21:259-268.

HALL, E.R. 1962. Collecting and preparing study specimens of vertebrates. University of Kansas, Museum of Natural History, Miscellaneous Publication 30.

Higgins, K.F., E.D. Stukel, J.M. Goulet, and D.C. BACKLUND. 2002. Wild mammals of South Dakota. 2nd edition. South Dakota Department of Game, Fish and Parks, Pierre.

Hudson, J.C. 2002. Across this land: a regional geography of the United States and Canada. Johns Hopkins University Press, Baltimore, MD.

Jones, C., W.J. McShea, M.J. Conroy, and T.H. Kunz. 1996. Capturing mammals. Pages 115-156 in D.E. Wilson, F.R. Cole, J.D. Nichols, R. Rudran, and M.S. Foster, editors, Measuring and monitoring biological diversity: standard methods for mammals. Smithsonian Institution Press, Washington, DC.

Jones, J.K., JR. 1964. Distribution and taxonomy of mammals of Nebraska. University of Kansas Publications, Museum of Natural History 16:1-356.

Jones, J.K., JR., J.R. ChOATE, AND R.B. Wilhelm. 1978. Notes on distribution of three species of mammals in South Dakota. Prairie Naturalist 10:65-70.

Martin, R.A. 1971. Small mammals from Barn Owl pellets. South Dakota Bird Notes 23:4-10.

McCaRTHY, M.A. 1998. Identifying declining and threatened species with museum data. Biological Conservation 83:9-17.

MCNAB, B.K. 1980. Energetics and the limits to a temperate distribution in armadillos. Journal of Mammalogy 61:606-627. 
Merriam, D.F. 2002. The armadillo [Dasypus novemcinctus (Linnaeus)] invasion of Kansas. Transactions of the Kansas Academy of Science 105:44-50.

Millspaugh, J.J., G.C. Brundige, R.A. Gitzen, and K.J. RAEDEKE. 2000. Elk and hunter space-use sharing in South Dakota. Journal of Wildlife Management 64:994-1003.

Pergams, O.R.W., AND D. Nyberg. 2001. Museum collections of mammals corroborate the exceptional decline of prairie habitat in the Chicago region. Journal of Mammalogy 82:984-992.

Platt, S.G., Z. Fast Horse, S. Mannel, C. Comes Killing, AND T.R. Rainwater. 2006. A herpetofaunal survey of southwestern South Dakota with an emphasis on species of conservation concern. Journal Kansas Herpetology 20 (December):10-19.

Platt, S.G., K.R. Russell, W.E. Snyder, L.W. Fontenot, AND S. MiLleR. 1999. Distribution and conservation status of selected amphibians and reptiles in the piedmont of South Carolina. Journal of the Elisha Mitchell Scientific Society 115:8-19.

Raventon, E. 1994. Island in the Plains: a Black Hills natural history. Johnson Books, Boulder, CO.

Remsen, J.V., JR. 1995. The importance of continued collecting of bird specimens to ornithology and bird conservation. Bird Conservation International 5:145-180.

Shaffer, H.B., R.N. Fisher, and C. Davidson. 1998. The role of natural history collections in documenting species declines. Trends in Ecology and Evolution 13:27-30.

Stebler, A.M. 1939. An ecological study of the mammals of the Badlands and the Black Hills of South Dakota and Wyoming. Ecology 20:382-393.

Taulman, J.F., and L.Y. Robbins. 1996. Recent range expansion and distributional limits of the ninebanded armadillo (Dasypus novemcinctus) in the United States. Journal of Biogeography 23:635-648.

Turner, R.W. 1974. Mammals of the Black Hills of South Dakota and Wyoming. University of Kansas Publications, Museum of Natural History 60:1-178.

Van Deelen, T.R., J.D. Parkis, and E.J. Heske. 2002. A nine-banded armadillo (Dasypus novemcinctus) from central Illinois. Southwestern Naturalist 47:489-491.

Wilhelm, R.B., J.R. Choate, and J.K. Jones, JR. 1981. Mammals of Lacreek National Wildlife Refuge, South Dakota. Special Publications, The Museum, Texas Tech University 17:3-39.

WINKER, K. 1996. The crumbling infrastructure of biodiversity: the avian example. Conservation Biology 10:703-707.

Received 14 April 2008 Accepted 28 May 2009 